\title{
KOMPARASI KINERJA PERBANKAN SYARIAH DI ASIA DENGAN PENDEKATAN MAQASID SYARIAH
}

\author{
Rilanda Adzhani dan Rini \\ Universitas Islam Negeri Syarif Hidayatullah Jakarta \\ Email: rini@uinjkt.ac.id
}

\begin{abstract}
The purpose of this research was to analyze whether there are differences the performance of Islamic banking in Asia, based on the concept of Maqasid al-Shari'ah, using MI (Maqasid Index) value. This research was using data from financial report and annual report which were provided by each Islamic bank sample. This research was using 3 samples of Islamic banks for each country (Indonesia, Malaysia, Iran, Saudi Arabia, United Arab Emirates, Kuwait, and Qatar), so the total sample of Islamic banks were 21 Islamic banks. The total observation were 63 during three years period (2013-2015). The Kolmogorov-Smirnov tests were used to test the normality of data and the hypothesis testing was using Analysis of Variance (ANOVA). The result of this research showed that MI value, second sharia objectives called establishing justice, and third sharia objectives called public interest in Islamic banking in Indonesia showed no significant difference with Islamic banking in Malaysia, Iran, Saudi Arabia, United Arab Emirates, Kuwait, and Qatar.
\end{abstract}

Keywords: $\quad$ The performance of Islamic banking, maqasid al-shari'ah, Simple Additive Weighting (SAW), Analysis of Variance (ANOVA), Asia.

\section{PENDAHULUAN}

Industri perbankan syariah atau sering disebut Islamic banking sudah ada dan telah berkembang dengan pesat dan cepat dalam beberapa dekade akhir-akhir ini seiring dengan pertumbuhan di dalam perekonomian global. Pertumbuhan yang begitu signifikan kemungkinan dipengaruhi oleh banyak faktor, yakni: ekonomi, politik, sosial, budaya, geografis, dan pertahanan keamanan (Wibowo, 2015).

Perbankan syariah memperoleh popularitas sejak awal tahun 1970 dan terdaftar pertumbuhan yang cukup besar selama bertahun-tahun. Neraca gabungan bank syariah tumbuh dari \$ 150 juta pada tahun 1990 menjadi sekitar \$ 1 milyar pada tahun 2010 dengan lebih dari 300 lembaga syariah yang beroperasi di 80 negara (Siraj and Pillai, 2012).

Tahun 2011 merupakan tahun yang luar biasa bagi pertumbuhan industri jasa keuangan di dunia. Pada tahun ini industri keuangan syariah menembus angka USD1.357 triliun. Penerbitan Sukuk tumbuh 77\% atau senilai USD85 milyar. Sedangkan pertumbuhan perbankan syariah global tumbuh $16,04 \%$. Tentunya ini adalah yang menggembirakan bagi industri keuangan syariah global. Berikut dijelaskan negara-negara yang mengalami 
pertumbuhan menurut Islamic Finance Index Country (IFCI) adalah Iran, Malaysia, Arab Saudi, Uni Emirat Arab, dan Indonesia.

Bank syariah mengalami ekspansi yang luar biasa. Bank syariah memperoleh pangsa pasar yang cepat di negara-negara domestik mereka. Tentunya, evaluasi kinerja bank syariah sangat penting karena efek globalisasi (Mokni, 2014).

Dalam penilaian Global Islamic Financial Report (GIFR) tahun 2016, Indonesia menduduki urutan keenam negara yang memiliki potensi dan kondusif dalam pengembangan industri keuangan syariah setelah Malaysia, Iran, Arab Saudi, Uni Emirat Arab, dan Kuwait. Seperti yang disampaikan dalam Ceramah Ilmiah Ikatan Ahli Ekonomi Islam (IAEI), dengan melihat beberapa aspek dalam penghitungan indeks, seperti jumlah bank syariah, jumlah lembaga keuangan non-bank syariah, maupun ukuran aset keuangan syariah yang memiliki bobot terbesar, maka Indonesia diproyeksikan akan menduduki peringkat pertama dalam beberapa tahun ke depan. Optimisme ini sejalan dengan laju ekspansi kelembagaan dan akselerasi pertumbuhan aset perbankan syariah yang sangat tinggi, ditambah dengan volume penerbitan sukuk yang terus meningkat.

Tabel 1. Islamic Finance Country Index (IFCI) Ranks for 2011 - 2016

\begin{tabular}{ccccccc}
\hline $\begin{array}{c}\text { Ran } \\
\mathrm{k}\end{array}$ & 2011 & 2012 & 2013 & 2014 & 2015 & 2016 \\
\hline 1 & Iran & Iran & Iran & Iran & Iran & Malaysia \\
\hline 2 & Malaysia & $\begin{array}{c}\text { Malaysi } \\
\mathrm{a}\end{array}$ & Malaysia & $\begin{array}{c}\text { Malaysi } \\
\mathrm{a}\end{array}$ & $\begin{array}{c}\text { Malaysi } \\
\mathrm{a}\end{array}$ & Iran \\
\hline 3 & $\begin{array}{c}\text { Saudi } \\
\text { Arabia }\end{array}$ & $\begin{array}{c}\text { Saudi } \\
\text { Arabia }\end{array}$ & $\begin{array}{c}\text { Saudi } \\
\text { Arabia }\end{array}$ & $\begin{array}{c}\text { Saudi } \\
\text { Arabia }\end{array}$ & $\begin{array}{c}\text { Saudi } \\
\text { Arabia }\end{array}$ & $\begin{array}{c}\text { Saudi } \\
\text { Arabia }\end{array}$ \\
\hline 4 & Indonesia & Kuwait & UAE & Bahrain & UAE & UAE \\
\hline 5 & Kuwait & UAE & Indonesia & Kuwait & Kuwait & Kuwait \\
\hline 6 & Pakistan & Bahrain & Bahrain & UAE & Bahrain & Indonesia \\
\hline 7 & UAE & $\begin{array}{c}\text { Indonesi } \\
\text { a }\end{array}$ & Kuwait & $\begin{array}{c}\text { Indonesi } \\
\text { a }\end{array}$ & $\begin{array}{c}\text { Indonesi } \\
\text { a }\end{array}$ & Qatar \\
\hline 8 & Bahrain & Pakistan & Pakistan & Sudan & Qatar & Bahrain \\
\hline 9 & $\begin{array}{c}\text { Banglade } \\
\text { sh }\end{array}$ & Qatar & Sudan & Pakistan & Sudan & Pakistan \\
\hline 10 & Sudan & Sudan & $\begin{array}{c}\text { Banglade } \\
\text { sh }\end{array}$ & Qatar & Pakistan & $\begin{array}{c}\text { Banglade } \\
\text { sh }\end{array}$ \\
\hline
\end{tabular}

Source: Global Islamic Financial Report (GIFR) 2016

Sekarang ini, lingkungan internasional dan domestik dimana bank syariah beroperasi akan menjadi lebih menantang. Karena situasi ini, penting untuk lembaga perbankan syariah untuk memperkuat kinerja bisnis mereka dalam rangka untuk menghadapi persaingan kuat dari bank domestik dan asing (bank syariah maupun konvensional). Profitabilitas yang sehat dan berkelanjutan sangat penting dalam menjaga stabilitas sistem perbankan (Idris, 2011). 
Jika dilihat dari kuatnya persaingan perbankan syariah yang ada saat ini, maka memperkuat kinerja bisnis merupakan keharusan yang dilakukan oleh setiap bank syariah yang ada di seluruh dunia untuk mempertahankan dan mengembangkannya. Oleh karena itu, hal yang menarik untuk menganalisis perbandingkan kinerja perbankan syariah antarnegara di dunia, khususnya di Asia yang memiliki negara-negara dengan perkembangan perbankan syariah yang luar biasa, dan apakah terdapat perbedaan kinerja antara negara-negara tersebut.

\section{KAJIAN TEORI}

\subsection{PENGUKURAN KINERJA PERBANKAN SYARIAH}

Pengukuran kinerja menurut Horngren (1993: 372) mempunyai tujuan untuk mengukur kinerja bisnis dan manajemen dibandingkan dengan goal atau sasaran perusahaan. Dengan kata lain, pengukuran kinerja merupakan alat bagi manajemen untuk mengendalikan bisnisnya.

Pengukuran kinerja pada bank syariah kebanyakan masih menggunakan pengukuran yang sama dengan pengukuran kinerja pada bank konvensional yaitu dengan menghitung rasio CAMELS (Capital, Asset, Management, Earning, Liquidity, Sensitivity of Market Risk). Jika dilihat dari tujuan perbankan syariah, seharusnya pengukuran yang digunakan untuk mengukur kinerja perbankan syariah lebih spesifik dan diarahkan kepada tujuan yang ingin dicapai berdasarkan syariah, sehingga dapat mencerminkan bagaimana tujuan-tujuan syariah terpenuhi.

\subsection{KINERJA PERBANKAN SYARIAH DENGAN MAQASID AL-SHARI'AH FRAMEWORK}

Maqasid al-Shari'ah framework adalah kerangka atau model pengukuran kinerja perbankan syariah yang sesuai dengan tujuan dan karakteristik perbankan syariah. Dalam penelitian ini, penulis menggunakan konsep tujuan syariah berdasarkan Abu Zaharah (1997) seperti beberapa penelitian yang telah dilakukan sebelumnya. Menurut Abu Zahara (1997), secara spesifik perbankan syariah memiliki tiga tujuan utama yang harus dipenuhi, yaitu:

\section{a. Tahdhib al-Fard (Pendidikan Individu)}

Tujuan pertama mengungkapkan tentang bagaimana seharusnya perbankan syariah menyebarkan pengetahuan dan kemampuan serta menanamkan nilainilai individu untuk perkembangan spiritualnya. Dengan demikian, bank syariah harus merancang program pendidikan dan pelatihan yang harus mengembangkan tenaga kerja yang berpengetahuan dan terampil dengan nilai-nilai moral yang tepat. Mereka juga harus menyebarkan informasi kepada stakeholder mengenai produk mereka.

b. Iqamah al- 'Adl (Pembentukan Keadilan) 
Tujuan kedua yaitu perbankan syariah harus meyakinkan bahwa setiap transaksi dalam aktivitas bisnis dilakukan secara adil termasuk produk, harga, ketentuan, dan kondisi kontrak. Selain itu perbankan syariah juga harus meyakinkan bahwa setiap bisnis perbankan bebas dari elemen-elemen negatif yang dapat menciptakan ketidakadilan seperti riba, kecurangan, dan korupsi. Secara tidak langsung, bank harus bijak menggunakan keuntungan dan mengarahkan kegiatan ke arah yang dapat membantu mengurangi ketidaksetaraan pendapatan dan kekayaan.

\section{c. Jalb al-Maslahah (Kepentingan Publik)}

Tujuan ketiga yaitu perbankan syariah harus membuat prioritas mengenai aktivitas bisnis mana yang memberikan manfaat yang lebih besar bagi masyarakat. Tujuan ini termasuk kegiatan yang mencakup kebutuhan dasar masyarkat seperti investasi di sektor-sektor vital, pembiayaan proyek perumahan, dan lain sebagainya.

Konsep ini merupakan adaptasi dari konsep yang dikemukakan oleh Abu Zahara (1997) dalam Mohammed et al (2008, 2015). Ketiga tujuan diatas oleh Mohammed et al $(2008,2015)$ diturunkan menjadi beberapa indikator pengukuran dengan menggunakan metode operasionalisasi Sekaran. Hal ini dilakukan agar ketiga tujuan syariah diatas dapat secara operasional diukur dan ditentukan nilainya. Dengan menggunakan metode Sekaran, penilaian kinerja perbankan syariah berdasarkan konsep Maqasid al-Shari'ah yang dirumuskan oleh para peneliti adalah sebagai berikut:

Tabel 2. Model Pengukuran Kinerja Perbankan Syariah

\begin{tabular}{|c|c|c|c|}
\hline $\begin{array}{c}\text { Concepts } \\
\text { (Objectives) }\end{array}$ & Dimensions & Elements & Performance Ratios \\
\hline \multirow[t]{4}{*}{$\begin{array}{l}1 . \\
\text { Educating } \\
\text { Individual }\end{array}$} & $\begin{array}{l}\text { D1. } \\
\text { Advancement of } \\
\text { Knowledge }\end{array}$ & $\begin{array}{l}\text { E1. } \\
\text { Education } \\
\text { Grant }\end{array}$ & $\begin{array}{l}\text { R1. Education Grant or } \\
\text { Scholarship/ Total } \\
\text { Expenses }\end{array}$ \\
\hline & & E2. Research & $\begin{array}{l}\text { R2. Research Expenses/ } \\
\text { Total Expenses }\end{array}$ \\
\hline & $\begin{array}{l}\text { D2. Instilling } \\
\text { New Skills and } \\
\text { Improvements }\end{array}$ & E3. Training & $\begin{array}{l}\text { R3. Training Expenses/ } \\
\text { Total Expenses }\end{array}$ \\
\hline & $\begin{array}{l}\text { D3. Creating } \\
\text { Awareness of } \\
\text { Islamic Banking }\end{array}$ & E4. Publicity & $\begin{array}{l}\text { R4. Publicity Expenses/ } \\
\text { Total Expenses }\end{array}$ \\
\hline $\begin{array}{l}2 . \\
\text { Establishing } \\
\text { Justice }\end{array}$ & D4. Fair Returns & $\begin{array}{l}\text { E5. Fair } \\
\text { Returns }\end{array}$ & $\begin{array}{l}\text { R5. Profit Equalization } \\
\text { Reserves (PER)/ Net or } \\
\text { Investment Income }\end{array}$ \\
\hline
\end{tabular}




\begin{tabular}{|c|c|c|c|}
\hline \multirow[t]{3}{*}{$\begin{array}{c}\text { Concepts } \\
\text { (Objectives) }\end{array}$} & Dimensions & Elements & Performance Ratios \\
\hline & $\begin{array}{l}\text { D5. Cheap } \\
\text { Product and } \\
\text { Services }\end{array}$ & $\begin{array}{l}\text { E6. } \\
\text { Functional } \\
\text { Distribution }\end{array}$ & $\begin{array}{l}\text { R6. Mudharabah and } \\
\text { Musharakah Modes/ } \\
\text { Total Investment Modes }\end{array}$ \\
\hline & $\begin{array}{l}\text { D6. Elimination } \\
\text { of Negative } \\
\text { Elements that } \\
\text { Breed Injustices }\end{array}$ & $\begin{array}{l}\text { E7. Interest } \\
\text { Free Product }\end{array}$ & $\begin{array}{l}\text { R7. Interest Free Income/ } \\
\text { Total Income }\end{array}$ \\
\hline \multirow[t]{3}{*}{ 3. Maslahah } & $\begin{array}{l}\text { D7. Profitability } \\
\text { of Bank }\end{array}$ & $\begin{array}{l}\text { E8. Profit } \\
\text { Ratio }\end{array}$ & $\begin{array}{l}\text { R8. Net Income/ Total } \\
\text { Assets }\end{array}$ \\
\hline & $\begin{array}{l}\text { D8. } \\
\text { Redistribution of } \\
\text { Income and } \\
\text { Wealth }\end{array}$ & $\begin{array}{l}\text { E9. Personal } \\
\text { Income }\end{array}$ & $\begin{array}{l}\text { E9. Zakah Paid/ Net } \\
\text { Asset }\end{array}$ \\
\hline & $\begin{array}{l}\text { D9. Investment } \\
\text { in Vital Real } \\
\text { Sector }\end{array}$ & $\begin{array}{l}\text { E10. } \\
\text { Investment } \\
\text { Ratio in Real } \\
\text { Sector }\end{array}$ & $\begin{array}{l}\text { R10. Investment in Real } \\
\text { Economic Sector/ Total } \\
\text { Investment }\end{array}$ \\
\hline
\end{tabular}

Sumber: Mohammed et al (2015)

Untuk mendapatkan hasil yang terbaik dari pengukuran di atas, maka dilakukan verifikasi dari model dan pembobotan pada setiap konsep dan elemen pengukuran melalui wawancara dengan 16 pakar syariah di Malaysia dan Timur Tengah. Bobot rata-rata yang diberikan adalah sebagai berikut (Mohammed et.al, 2015):

Tabel 3. Bobot Rata-Rata untuk Tiga Tujuan dan Sepuluh Elemen

\begin{tabular}{|c|c|c|c|}
\hline Variabel & $\begin{array}{c}\text { Bobot } \\
\text { Variabel } \\
(\%)\end{array}$ & Atribut & $\begin{array}{c}\text { Bobot } \\
\text { Atribut } \\
(\%)\end{array}$ \\
\hline \multirow{5}{*}{$\begin{array}{l}1 . \\
\text { Pendidikan } \\
\text { (Tahdib Al- } \\
\text { Fard) }\end{array}$} & \multirow{5}{*}{30} & E1. Hibah & 24 \\
\hline & & E2. Penelitian & 27 \\
\hline & & E3. Pelatihan & 26 \\
\hline & & E4. Publikasi & 23 \\
\hline & & Total & 100 \\
\hline \multirow{4}{*}{$\begin{array}{l}2 . \\
\text { Mewujudkan } \\
\text { Keadilan } \\
\text { (Al-'Adl) }\end{array}$} & \multirow{4}{*}{41} & E1. Pengembalian yang & 30 \\
\hline & & E2. Harga yang Adil & 32 \\
\hline & & E3. Produk Bebas Bunga & 38 \\
\hline & & Total & 100 \\
\hline \multirow{2}{*}{$\begin{array}{l}3 . \\
\text { Kepentingan }\end{array}$} & & E1. Rasio Profitabilitas & 33 \\
\hline & & E2. Pemerataan Pendapatan & 30 \\
\hline
\end{tabular}




\begin{tabular}{lclc}
$\begin{array}{l}\text { Publik } \\
\text { (Maslahah) }\end{array}$ & 29 & E3. Investasi pada Sektor & 37 \\
\cline { 3 - 3 } & & Total & 100 \\
\hline
\end{tabular}

Sumber: Mohammad et al (2015) dan Ramadhani dan Mutia (2016)

\subsection{PERUMUSAN HIPOTESIS}

Pengukuran kinerja perbankan syariah tidak hanya dapat diukur oleh rasiorasio keuangan saja, melainkan merupakan suatu konsep baru untuk mengukur kinerja perbankan syariah yang dikembangkan oleh para peneliti muslim dari seluruh dunia. Konsep pengukuran yang dirumuskan tersebut menggunakan konsep Maqasid al-Shari'ah yang mencakup aspek ekonomi, lingkungan, serta indikator sosial (Antonio, 2012). Pengukuran dengan maqasid index syariah dapat digunakan untuk mengetahui sampai sejauh mana tingkat pencapaian nilai-nilai syariah yang dijalankan pada perbankan syariah.

Perbankan syariah di Indonesia, Malaysia, Iran, Arab Saudi, Uni Emirat Arab, Kuwait, dan Qatar merupakan negara-negara di dunia yang saat ini sedang mengalami perkembangan pesat terhadap perbankan syariahnya. Sebagai negara-negara yang sedang mengalami perkembangan, perbankan syariah di ketujuh negara tersebut juga memiliki karakteristik yang berbeda dalam interpretasi mazhab yang dianut oleh ketujuh negara tersebut. Hal ini akan memengaruhi akad dan produk yang terdapat pada perbankan syariah di ketujuh negara. Perbedaan ini juga akan memengaruhi nilai maqasid index secara keseluruhan dan akan memengaruhi nilai tujuan pembentukan keadilan secara khusus. Oleh karena itu, hipotesisnya adalah sebagai berikut:

$\mathrm{H}_{1}$ : Terdapat perbedaan pada nilai Maqasid Index (MI) antara perbankan syariah di Indonesia dengan perbankan syariah di Malaysia, Iran, Arab Saudi, Uni Emirat Arab, Kuwait, dan Qatar.

Tujuan syariah pembentukan keadilan menggambarkan sampai sejauh mana perbankan syariah Indonesia dengan perbankan syariah Malaysia, Iran, Arab Saudi, Uni Emirat Arab, Kuwait, dan Qatar mampu mencapai nilai tujuan syariah berupa keadilan masing-masing stakeholder dapat tercapai. Tujuan ini diturunkan menjadi tiga elemen yaitu fair return, distribusi fungsional, dan produk bebas bunga. Perbankan syariah dari tujuh negara tersebut memiliki karakteristik yang berbeda yang akan berimplikasi pada akad dan produk yang terdapat pada perbankan syariah seperti akad bagi hasil atau jual beli. Oleh karena itu, hipotesis kedua dirumuskan sebagai berikut:

H2: Terdapat perbedaan pada nilai tujuan pembentukan keadilan antara perbankan syariah di Indonesia dengan perbankan syariah di Malaysia, Iran, Arab Saudi, Uni Emirat Arab, Kuwait, dan Qatar.

Tujuan syariah kepentingan publik menggambarkan sampai sejauh mana perbankan syariah di Indonesia dengan perbankan syariah di Malaysia, Iran, Arab Saudi, Uni Emirat Arab, Kuwait, dan Qatar mampu mencapai nilai tujuan syariah berupa pemenuhan hak-hak bank syariah untuk kepentingan 
bank itu sendiri maupun pemenuhan hak-hak masyarakat. Tujuan ini diturunkan menjadi tiga elemen yaitu rasio laba, pendapatan personal, dan rasio investasi pada sektor riil. Perbankan syariah dari tujuh negara tersebut memiliki karakteristik yang berbeda yang akan memengaruhi penekanan terhadap investasi, apakah perbankan syariah akan menekankan pada sektor riil atau sektor moneter. Hal ini akan berimplikasi pada nilai yang membentuk tujuan kepentingan publik. Dengan demikian, hipotesis ketiga dirumuskan sebagai berikut:

$\mathrm{H}_{3}$ : Terdapat perbedaan pada nilai tujuan kepentingan publik antara perbankan syariah di Indonesia dengan perbankan syariah di Malaysia, Iran, Arab Saudi, Uni Emirat Arab, Kuwait, dan Qatar.

\section{METODE PENELITIAN}

\subsection{RUANG LINGKUP PENELITIAN}

Penelitian ini bertujuan untuk melakukan analisis komparatif atas kinerja bank syariah dengan pendekatan maqasid syariah di Asia. Untuk itu dilakukan analisis atas Laporan Tahunan (Annual Report) dan Laporan Keuangan Tahunan (Financial Report) yang diterbitkan dan dipublikasikan oleh sejumlah bank syariah di beberapa negara Asia.

\subsection{METODE PENENTUAN SAMPEL}

Populasi dalam penelitian ini adalah bank-bank syariah yang ada di Asia, sedangkan sampel dalam penelitian ini adalah bank-bank syariah yang terdapat di negara yang termasuk enam besar dalam Islamic Finance Country Index. Keenam Negara tersebut adalah Indonesia, Malaysia, Iran, Arab Saudi, Uni Emirat Arab, Kuwait, dan Qatar. Penentuan sampel dari populasi pada penelitian ini diperoleh dengan purposive sampling atau pemilihan sampel bertujuan. Adapun kriteria Bank Syariah yang dijadikan sampel adalah sebagai berikut:

Bank Syariah yang beroperasi pada tahun 2013, 2014, dan 2015

Bank Syariah yang menyajikan data Laporan Tahunan atau Laporan Keuangan Tahunan pada tahun 2013, 2014, dan 2015

Setelah mempelajari ketersediaan data dan untuk analisis komparatif dengan ANOVA, dimana jumlah data harus sama, maka ditetapkan tiga bank dari masing-masing negara secara acak. Bank syariah yang terpilih sebagai sampel dari enam negara tersebut adalah sebagai berikut:

a. Indonesia : Bank Syariah Mandiri, Bank Mega Syariah, dan BNI Syariah;

b. Malaysia : Bank Islam Malaysia Berhad, Bank Muamalat Malaysia Berhad, dan CIMB Islamic Bank Berhad; 
c. Iran

d. Arab Saudi

e. UEA

f. Kuwait

g. Qatar
: Parsian Bank, Tejarat Bank, dan Saman Bank;

: Al Rajhi Bank, Alinma Bank, dan Bank AlJazira;

: Abu Dhabi Islamic Bank, Dubai Islamic Bank, dan Emirates Islamic Bank;

: Kuwait Finance House, Ahli United Bank, dan Boubyan Bank;

: Qatar Islamic Bank, Masraf Al Rayan, dan Barwa Bank.

\subsection{METODE PENGUMPULAN DATA}

Data yang dikumpulkan dalam penelitian ini adalah data sekunder. Data sekunder yang diperoleh meliputi Laporan Tahunan (Annual Report) dan Laporan Keuangan Tahunan (Financial Report) yang diterbitkan dan dipublikasikan dalam situs resmi oleh masing-masing bank syariah. Pengukuran kinerja dengan pendekatan maqasid syariah dibatasi hanya pada tujuan kedua (pembentukan keadilan) dan ketiga (kepentingan publik), karena ketidaktersediaan data secara lengkap dari bank syariah di enam negara diatas. Sejumlah bank yang terpilih di Arab Saudi dan Kuwait sama sekali tidak mempublikasikan data yang dibutuhkan untuk tujuan pertama (pendidikan). Sedangkan untuk Negara Malaysia, Uni Emirat Arab, Iran dan Qatar, sebagian bank mengungkapkan data pendidikannya dalam laporan keuangan, sebagian lagi tidak mengungkapkan.

Dari laporan tahunan dan laporan keuangan tahunan, dibuatlah rasiorasio yang sesuai dengan tujuan-tujuan syariah berdasarkan maqasid alshari'ah yang telah ditetapkan sebelumnya yang pada akhirnya digunakan untuk analisis.

\subsubsection{Tujuan Pembentukan Keadilan}

Tujuan pembentukan keadilan merupakan upaya bank syariah dalam memastikan kejujuran dan keadilan dalam semua transaksi, maupun kegiatan usaha yang dapat menciptakan ketidakadilan seperti riba, kecurangan, dan korupsi. Tujuan maqasid al-shari'ah kedua ini diturunkan menjadi 3 elemen (fair returns, distribusi fungsional, dan produk bebas bunga) dan dapat diukur dengan rasio-rasio berikut ini:

a. Fair returns digambarkan dengan seberapa besar persentase laba dibagi dengan total pendapatan. Rasio ini merupakan satu-satunya rasio yang memiliki nilai pengurang dalam pembobotan nilai maqasid index. Semakin rendah laba atau keuntungan yang diterima oleh bank dibandingkan dengan total pendapatan, maka bank syariah tersebut dinilai semakin menerapkan tujuan pencapaian keadilan (Rusdiyana dalam Imansari, 2015). Formula yang digunakan untuk rasio ini adalah (Mohammed et al, 2008):

Fair Returns = Laba $/$ Total Pendapatan 
b. Distribusi fungsional adalah rasio investasi mudarabah dan musharakah terhadap total investasi. Rasio ini menggambarkan seberapa besar bank syariah mengalokasikan dana untuk aktivitas yang berlandaskan keadilan berupa terpeliharanya hak antara nasabah dengan bank syariah, yaitu akad mudarabah dan akad musharakah. Kedua akad tersebut menggunakan sistem bagi hasil (profit sharing). Semakin tinggi model pembiayaan bank syariah menggunakan mudarabah dan musharakah, maka menunjukkan bahwa bank syariah meningkatkan fungsinya untuk mewujudkan keadilan sosio-ekonomi melalui sistem bagi hasil. Formula untuk rasio ini adalah (Mohammed et al, 2015):

Distribusi Fungsional $=$ Investasi Mudarabah dan Musharakah $/$ Total Investasi

c. Rasio pendapatan bebas bunga terhadap total pendapatan menggambarkan bagaimana bank syariah dituntut untuk menjalankan aktivitas perbankan khususnya investasi yang dilakukan terbebas dari unsur riba (bunga). Semakin tinggi rasio pendapatan yang bebas bunga terhadap total pendapatannya, maka akan berdampak positif terhadap berkurangnya kesenjangan pendapatan dan kekayaan dalam kehidupan bermasyarakat. Formula yang digunakan untuk rasio ini adalah (Mohammed et al, 2015):

Produk Bebas Bunga = Pendapatan Bebas Bunga $/$ Total Pendapatan

\subsubsection{Tujuan Kepentingan Publik}

Tujuan syariah ketiga yaitu kepentingan publik (al-Maslahah) merupakan upaya bank syariah dalam memberikan manfaat yang lebih besar bagi masyarakat terhadap aktivitas bisnis yang dijalankannya. Tujuan ini diturunkan menjadi 3 elemen (rasio laba, pendapatan personal, dan rasio investasi pada sektor riil) dan dapat diukur dengan rasio-rasio berikut ini:

a. Rasio laba atau profitabilitas merupakan kemampuan bank untuk menghasilkan atau memperoleh laba secara efektif dan efisien. Secara garis besar, laba yang dihasilkan perusahaan berasal dari penjualan dan pendapatan investasi yang dilakukan oleh perusahaan (Kasmir, 2002). Besarnya rasio ini dapat meggambarkan seberapa besar pencapaian nilai maslahat bagi bank syariah itu sendiri (Antonio, 2012). Menurut Mohammed et al (2015), semakin tinggi rasio menunjukkan kemampuan bank yang lebih tinggi untuk berkontribusi pada anggaran pemerintah dalam proyek-proyek pembangunan dan untuk pelayanan sosial, yang pada akhirnya dapat meningkatkan kesejahteraaan masyarakat. Formula yang digunakan untuk rasio ini adalah:

\section{Rasio Laba $=$ Laba Bersih $/$ Total Aset}

b. Elemen pendapatan personal dalam konsep maqasid al-shari'ah menunjukkan seberapa besar bank syariah dalam menyalurkan pendapatan dan kekayaannya kepada semua golongan. Hal ini dapat 
dilakukan bank syariah melalui pendistribusian atau penyaluran dana zakat yang dikeluarkan oleh bank syariah. Tingginya rasio zakat terhadap laba bersih menunjukkan transfer pendapatan dan kekayaan kepada orang yang tidak mampu dan yang membutuhkan, sehingga membantu dalam menangani kesenjangan ketidaksetaraan. Formula untuk rasio ini adalah (Mohammed et al, 2008):

\section{Pendapatan Personal $=$ Zakat $/$ Laba Bersih}

c. Rasio investasi pada sektor riil mengacu pada sejumlah sektor penting di mana bank syariah berinvestasi didalamnya. Sektor penting ini diberikan kepada sektor-sektor ekonomi riil yang memiliki implikasi langsung terhadap populasi yang lebih luas, terutama di daerah pedesaan. Sektor tersebut seperti pertanian, pertambangan, perikanan, konstruksi, manufaktur, dan bisnis skala kecil dan menengah. Tingginya rasio investasi pada sektor riil dapat menggambarkan seberapa besar pencapaian nilai maslahat untuk masyarakat, sehingga semakin tinggi nilai investasi untuk kegiatan pada sektor riil maka semakin besar pula manfaatnya untuk kemajuan ekonomi seluruh lapisan masyarakat. Formula yang digunakan untuk rasio ini adalah (Mohammed et al, 2015):

Rasio Investasi pada Sektor Riil = Investasi pada Sektor Ekonomi Riil $/$ Total Investasi

\subsection{METODE ANALISIS DATA}

Dalam penelitian ini peneliti menggunakan metode Simple Additive Weighting (SAW) seperti pada penelitian-penelitian sebelumnya. Metode ini digunakan untuk melihat seberapa besar pencapaian maqasid index (MI) pada perbankan syariah dengan melakukan penjumlahan masing-masing rasio yang memiliki bobot nilai tertentu yang telah ditentukan oleh pakar syariah di dunia (Antonio, 2012).

Setelah melakukan perhitungan nilai maqasid index dan nilai pertujuan syariah di ketujuh negara, maka peneliti melakukan metode analisis data kuantitatif yaitu Analysis of Variance (ANOVA), untuk membandingkan nilai rata-rata tiga atau lebih sampel yang tidak berhubungan. Dalam hal ini membandingkan rata-rata perbedaan kinerja secara keseluruhan berdasarkan maqasid al-shari'ah dan perbedaan tujuan syariah antara perbankan syariah di tujuh negara.

\subsubsection{Simple Additive Weighting}

a. Menghitung rasio kinerja pada masing-masing bank syariah. Rasiorasionya adalah:

$$
\begin{aligned}
& \text { R5 = Laba / Total Pendapatan } \\
& \text { R6 = Investasi Mudarabah dan Musharakah / Total Investasi } \\
& \text { R7 = Pendapatan Bebas Bunga / Total Pendapatan }
\end{aligned}
$$


R8 = Laba Bersih / Total Aset

R9 = Zakat / Laba Bersih

R10 = Investasi pada Sektor Ekonomi Riil / Total Investasi

Catatan: Empat rasio kinerja yang berkaitan dengan tujuan syariah pertama yaitu pendidikan individu telah dihilangkan dari analisis ini dikarenakan tidak tersedianya data yang memadai.

b. Melakukan pembobotan untuk masing-masing tujuan syariah sesuai dengan bobot rasio yang ditentukan dengan rumus sebagai berikut:

$\mathrm{IK} 12=\mathrm{B} 2 \times \mathrm{E} 5 \times \mathrm{R} 5$

$\mathrm{IK} 22=\mathrm{B} 2 \times \mathrm{E} 6 \times \mathrm{R} 6$

$\mathrm{IK} 32=\mathrm{B} 2 \times \mathrm{E} 7 \times \mathrm{R} 7$

$\mathrm{IK} 13=\mathrm{B} 3 \times \mathrm{E} 8 \times \mathrm{R} 8$

$\mathrm{IK} 23=\mathrm{B} 3 \times \mathrm{E} 9 \times \mathrm{R} 9$

$\mathrm{IK} 33=\mathrm{B} 3 \times \mathrm{E} 10 \times \mathrm{R} 10$

Keterangan:

IKn = Indikator Kinerja ke-n

$\mathrm{Bn}=$ Bobot untuk tujuan ke-n

En $=$ Bobot untuk elemen ke-n

$\mathrm{Rn}=$ Rasio ke-n

c. Menjumlahkan indikator kinerja masing-masing tujuan syariah untuk mengetahui nilai tujuan-tujuan syariah ketujuh negara dengan rumus sebagai berikut:

$\mathrm{IK}(\mathrm{T} 2)=-\mathrm{IK} 12+\mathrm{IK} 22+\mathrm{IK} 32$

$\mathrm{IK}(\mathrm{T} 3)=\mathrm{IK} 13+\mathrm{IK} 23+\mathrm{IK} 33$

Keterangan:

$\mathrm{IK}(\mathrm{Tn}) \quad=$ Tujuan ke-n

IKn = Indikator Kinerja ke-n

Catatan: IK12 yang merupakan indikator kinerja untuk rasio fair returns memiliki nilai pengurang dalam penjumlahan tujuan pembentukan keadilan (Rusdiyana dalam Imansari, 2015), sehingga semakin rendah nilainya akan semakin baik nilai tujuan pembentukan keadilannya.

d. Menjumlahkan nilai tujuan-tujuan untuk mengetahui nilai maqasid index (MI) ketujuh negara dengan rumus sebagai berikut:

$\mathrm{MI}=\mathrm{IK}(\mathrm{T} 2)+\mathrm{IK}(\mathrm{T} 3)$ 
Keterangan:

MI

$$
\text { = Maqasid Index }
$$

IK (T2) = Tujuan Pembentukan Keadilan

IK (T3) = Tujuan Kepentingan Publik

Bank syariah yang memiliki hasil penjumlahan tertinggi akan memiliki peringkat yang tinggi pula dalam pencapaian tujuannya. Setelah semua nilai maqasid al-shari'ah diketahui pada masing-masing bank, maka dilanjutkan dengan melakukan analisis deskriptif dan uji ANOVA.

\subsubsection{Statistik Deskriptif}

Statistik deskriptif memberikan gambaran atau deskripsi suatu data yang dilihat dari nilai rata-rata (mean), standar deviasi, varian, maksimum, minimum, sum, range, kurtosis, dan skewness (kemencengan distribusi) (Ghozali, 2013:19). Perbedaan kinerja tujuh negara akan terlihat pada nilai rata-rata (mean) masing-masing rasio, dan hal itu belum dapat digunakan untuk menguji hipotesis, karena itu diperlukan uji perbedaan lebih lanjut dengan menyesuaikan distribusi datanya.

\subsubsection{Uji Normalitas Data}

Uji statistik yang digunakan untuk mendeteksi normalitas data dalam penelitian ini adalah dengan uji Kolmogorov-Smirnov (K-S). Uji K-S dilakukan dengan membuat hipotesis pengujian (Ghozali, 2013:32):

H0 : Data terdistribusi secara normal

Ha : Data tidak terdistribusi secara normal

\subsubsection{Uji Hipotesis}

Uji hipotesis dilakukan dengan analysis of variance (ANOVA) yang digunakan untuk menguji apakah seluruh sampel mempunyai rata-rata (mean) yang sama dengan hipotesis. Untuk dapat menggunakan uji statistik ANOVA harus dipenuhi beberapa asumsi di bawah ini (Ghozali, 2013:70):

a. Homogeneity of Variance

Variabel dependen harus memiliki varian yang sama dalam setiap kategori variabel independen. Jika terdapat lebih dari satu variabel independen, maka harus ada homogeneity of variance di dalam cell yang dibentuk oleh variabel independen kategorikal. SPSS memberikan test ini dengan nama Levene's test of homogeneity of variance. Jika nilai Levene test signifikan (probabilitas < 0.05) maka hipotesis nol akan ditolak bahwa grup memiliki varian yang berbeda dan hal ini menyalahi asumsi. Jadi yang dikehendaki adalah tidak dapat menolak hipotesis nol atau hasil Levene test tidak signifikan (probabilitas >0.05).

b. Random Sampling 
Untuk tujuan uji signifikansi, maka subyek di dalam setiap grup harus diambil secara random.

c. Multivariate Normality

Untuk tujuan uji signifikansi, maka variabel harus mengikuti distribusi normal multivariate. Variabel dependen terdistribusi secara normal dalam setiap kategori variabel independen. ANOVA masih tetap robust walaupun terdapat penyimpangan asumsi multivariate normality. SPSS memberikan uji Boxplot test of the normality assumption.

ANOVA yang digunakan untuk membandingkan nilai rata-rata tiga atau lebih sampel yang tidak berhubungan pada dasarnya adalah menggunakan $\mathrm{F}$ test yaitu:

\section{d. Post Hoc Test}

$$
F=\frac{\text { between groups estimated variance mean squares }}{\text { within groups estimated variance mean squares }}
$$

Digunakan untuk mencari mana saja region yang berbeda dan mana saja region yang tidak berbeda. Analisis dilakukan dengan melihat Tukey test dan Bonferroni test, dimana Tukey test untuk sampel yang sama, sedangkan Bonferroni test untuk sampel yang berbeda. Apa bila pada kolom mean difference terdapat tanda "(*)" maka terdapat perbedaan yang signifikan.

e. Homogenus Sub

Digunakan untuk mencari grup atau sub mana saja yang terlihat bahwa keempat sampel berada dalam satu sub yang menandakan tidak terdapat perbedaan dan jika ada perbedaan signifikan, maka keempat sampel akan terkelompokkan ke dalam empat sub yang berbeda.

\section{HASIL DAN PEMBAHASAN}

\subsection{RASIO KINERJA BANK SYARIAH}

Tabel 4. Rasio Kinerja Maqasid al-Shari'ah

\begin{tabular}{|c|c|c|c|c|c|c|c|}
\hline \multirow[t]{2}{*}{ Negara } & \multirow[t]{2}{*}{ Bank } & \multicolumn{3}{|c|}{$\begin{array}{c}\text { RK Tujuan Kedua } \\
\text { Rasio Rata-Rata (2013- } \\
\text { 2015) }\end{array}$} & \multicolumn{3}{|c|}{$\begin{array}{c}\text { RK Tujuan Ketiga } \\
\text { Rasio Rata-Rata (2013- } \\
\text { 2015) }\end{array}$} \\
\hline & & R5 & R6 & $\mathrm{R} 7$ & $\mathrm{R} 8$ & R9 & $\mathrm{R} 10$ \\
\hline \multirow{3}{*}{ Indonesia } & BSM & 0,0698 & 0,7898 & 0,1568 & 0,0045 & 0,2196 & 0,4575 \\
\hline & BMS & 0,0506 & 0,0939 & 0,2539 & 0,0070 & 0,1190 & 0,1039 \\
\hline & BNIS & 0,1153 & 0,5486 & 0,0644 & 0,0088 & 0,0628 & 0,1573 \\
\hline \multirow{3}{*}{ Malaysia } & BIMB & 0,2840 & 0,2843 & 0,0689 & 0,0109 & 0,0227 & 0,1089 \\
\hline & BMMB & 0,3243 & 0,5780 & 0,0904 & 0,0040 & 0,0384 & 0,1213 \\
\hline & CIMBI & 0,5085 & 0,0953 & 0,0956 & 0,0075 & 0,0000 & 0,0000 \\
\hline \multirow{2}{*}{ Iran } & $\mathrm{PB}$ & 0,3795 & 0,8092 & 0,2272 & 0,0116 & 0,0000 & 0,0000 \\
\hline & SB & 0,1361 & 0,7510 & 0,1079 & 0,0081 & 0,0000 & 0,0000 \\
\hline
\end{tabular}




\begin{tabular}{|c|c|c|c|c|c|c|c|}
\hline \multirow[t]{3}{*}{ Negara } & \multirow[t]{2}{*}{ Bank } & \multicolumn{3}{|c|}{$\begin{array}{c}\text { RK Tujuan Kedua } \\
\text { Rasio Rata-Rata (2013- } \\
\text { 2015) }\end{array}$} & \multicolumn{3}{|c|}{$\begin{array}{c}\text { RK Tujuan Ketiga } \\
\text { Rasio Rata-Rata (2013- } \\
\text { 2015) }\end{array}$} \\
\hline & & $\mathrm{R} 5$ & R6 & R7 & $\mathrm{R} 8$ & R9 & R10 \\
\hline & TB & 0,0772 & 0,4936 & 0,2328 & 0,0067 & 0,0000 & 0,0000 \\
\hline \multirow{3}{*}{$\begin{array}{l}\text { Arab } \\
\text { Saudi }\end{array}$} & ARB & 0,5187 & 0,0000 & 0,2710 & 0,0238 & 0,0529 & 0,3010 \\
\hline & $\mathrm{AB}$ & 0,4669 & 0,0000 & 0,1889 & 0,0161 & 0,2968 & 0,3597 \\
\hline & $\mathrm{BA}$ & 0,3499 & 0,0000 & 0,3010 & 0,0133 & 0,0250 & 0,4007 \\
\hline \multirow{3}{*}{$\begin{array}{l}\text { Uni } \\
\text { Emirat } \\
\text { Arab } \\
\text { (UEA) }\end{array}$} & ADIB & 0,3305 & 0,0284 & 0,2023 & 0,0153 & 0,0020 & 0,3036 \\
\hline & DIB & 0,5496 & 0,3235 & 0,1646 & 0,0211 & 0,0010 & 0,4461 \\
\hline & EIB & 0,6480 & 0,0654 & 0,1653 & 0,0080 & 0,0233 & 0,0000 \\
\hline \multirow{3}{*}{ Kuwait } & $\mathrm{KFH}$ & 0,4458 & 0,0000 & 0,1036 & 0,0101 & 0,0329 & 0,7703 \\
\hline & $\mathrm{BB}$ & 0,5583 & 0,0000 & 0,0994 & 0,0093 & 0,0102 & 0,0000 \\
\hline & AUB & 0,4724 & 0,0000 & 0,1160 & 0,0125 & 0,0105 & 0,0000 \\
\hline \multirow{3}{*}{ Qatar } & QIB & 0,7022 & 0,0420 & 0,1260 & 0,0168 & 0,0000 & 0,2673 \\
\hline & MAR & 0,8160 & 0,1926 & 0,0659 & 0,0252 & 0,0000 & 0,0514 \\
\hline & BwB & 0,6341 & 0,0340 & 0,0850 & 0,0166 & 0,0000 & 0,4890 \\
\hline
\end{tabular}

Elemen kelima yaitu fair returns yang digambarkan melalui rasio laba dibandingkan dengan total pendapatan. Pada elemen kelima ini bank syariah Indonesia, yaitu Bank Mega Syariah (BMS), memiliki rasio sebesar 0,0506 atau 5,06\% yang menunjukkan bahwa bank dinilai semakin menerapkan tujuan pembentukan keadilan. Sebaliknya bank syariah Qatar, Masraf Al Rayan (MAR), memiliki rasio sebesar 0,8160 atau 81,60\% dikarenakan tingginya laba terhadap total pendapatan. Hal ini menunjukkan kurang baiknya nilai tujuan pembentukan keadilan pada Masraf Al Rayan (MAR).

Elemen keenam yaitu distribusi fungsional yang digambarkan oleh rasio investasi dengan skim bagi hasil (mudarabah dan musharakah) terhadap total investasi. Pada elemen keenam ini Parsian Bank (PB), yaitu bank syariah Iran, memiliki rasio paling tinggi sebesar 0,8092 atau 80,92\% dari total investasi yang menggunakan skim bagi hasil. Kemudian setelah Parsian Bank (PB) diikuti oleh Bank Syariah Mandiri (BSM) dari Indonesia dengan rasio sebesar 0,7898 atau 78,98\%.

Elemen kedelapan yaitu rasio laba yang menunjukkan kemampuan bank syariah untuk mengelola kekayaannya secara optimal dan bijaksana untuk memperoleh laba yang tinggi. Pada elemen kedelapan ini bank syariah Qatar, Masraf Al Rayan (MAR), memiliki rasio tertinggi sebesar 0,0252 atau 2,52\%. Hal ini menunjukkan laba bersih yang diperoleh Masraf Al Rayan adalah sebesar 2,52\% dari total aset yang dimilikinya. Setelah itu diikuti oleh Al Rajhi Bank (ARB) dari Arab Saudi yang memiliki nilai rasio tidak jauh berbeda dari Masraf Al Rayan (MAR) yaitu sebesar 0,0238 atau 2,38\%. Sedangkan tiga sampel bank syariah Indonesia dapat dikatakan masih rendah dalam kemampuan mengelola aset untuk memperoleh laba tinggi. 
Elemen ketujuh yaitu produk bebas bunga yang digambarkan melalui rasio pendapatan bebas bunga dibandingkan dengan total pendapatan. Bank AlJazira (BA) yaitu bank syariah dari Arab Saudi memiliki rasio tertinggi sebesar 0,3010 atau 30,10\% pada elemen ketujuh ini. Hal ini menunjukkan bahwa pendapatan Bank AlJazira (BA) dari aktivitas yang terbebas dari unsur riba (bunga) adalah $30,10 \%$ dari total pendapatannya. Sebaliknya bank syariah Indonesia, BNI Syariah (BNIS), memiliki rasio paling rendah sebesar 0,0644 atau $6,44 \%$ dikarenakan rendahnya pendapatan bebas bunga terhadap total pendapatan.

Elemen kesembilan yaitu pendapatan personal yang digambarkan oleh rasio zakat yang dikeluarkan oleh bank syariah terhadap laba bersihnya. CIMB Islamic Malaysia, tiga sampel bank syariah di Iran, dan tiga sampel bank syariah di Qatar, tidak mempublikasikan di laporan keuangan besarnya zakat yang dikeluarkan. Rasio paling tinggi pada elemen kesembilan ini adalah Alinma Bank (AB) yaitu bank syariah dari Arab Saudi dengan nilai sebesar 0,2968 atau 29,68\%. Ini berarti besarnya zakat yang dikeluarkan Alinma Bank (AB) setara dengan 29,68\% dari laba bersihnya. Selanjutnya diikuti oleh bank syariah dari Indonesia, Bank Syariah Mandiri (BSM), zakat yang dikeluarkan setara dengan 21,96\% dari laba bersihnya.

Elemen kesepuluh yaitu rasio investasi pada sektor riil yang digambarkan oleh investasi bank syariah pada sektor ekonomi riil dibandingkan dengan seluruh investasi bank syariah. Bank syariah Kuwait yaitu Kuwait Finance House (KFH) memiliki rasio paling tinggi sebesar 0,7703 yang menunjukkan $77,03 \%$ dari total investasinya disalurkan untuk investasi di sektor ekonomi riil. Setelah Kuwait Finance House (KFH) diikuti oleh Barwa Bank (BwB) dari Qatar dan Bank Syariah Mandiri (BSM) dari Indonesia yang memiliki nilai rasio tidak jauh berbeda yaitu sebesar 0,4890 dan 0,4575 .

\subsection{INDIKATOR KINERJA BANK SYARIAH}

Tabel 5. Indikator Kinerja Maqasid al-Shari'ah

\begin{tabular}{|c|c|c|c|c|c|c|c|c|c|}
\hline \multirow{2}{*}{ Negara } & \multirow{2}{*}{ Bank } & \multicolumn{4}{|c|}{ IK untuk Tujuan Kedua } & \multicolumn{4}{|c|}{ IK untuk Tujuan Ketiga } \\
\hline & & IK12 & IK22 & IK32 & Total2 & IK13 & IK23 & IK33 & Total3 \\
\hline \multirow{6}{*}{$\begin{array}{l}\text { Indone } \\
\text { sia }\end{array}$} & \multirow{2}{*}{ BSM } & 0,008 & 0,103 & 0,024 & 0,136 & 0,000 & 0,019 & 0,049 & 0,068 \\
\hline & & 59 & 63 & 43 & 64 & 43 & 10 & 09 & 63 \\
\hline & \multirow{2}{*}{ BMS } & 0,006 & 0,012 & 0,039 & 0,058 & 0,000 & 0,010 & 0,011 & 0,022 \\
\hline & & 22 & 32 & 56 & 10 & 67 & 35 & 15 & 17 \\
\hline & \multirow{2}{*}{ BNIS } & 0,014 & 0,071 & 0,010 & 0,096 & 0,000 & 0,005 & 0,016 & 0,023 \\
\hline & & 19 & 98 & 03 & 19 & 84 & 46 & 87 & 18 \\
\hline \multirow{6}{*}{$\begin{array}{l}\text { Malays } \\
\text { ia }\end{array}$} & BIM & 0,034 & 0,037 & 0,010 & 0,082 & 0,001 & 0,001 & 0,011 & 0,014 \\
\hline & $\mathrm{B}$ & 93 & 31 & 74 & 98 & 05 & 98 & 69 & 71 \\
\hline & BMM & 0,039 & 0,075 & 0,014 & 0,129 & 0,000 & 0,003 & 0,013 & 0,016 \\
\hline & $\mathrm{B}$ & 89 & 83 & 08 & 81 & 38 & 34 & 02 & 74 \\
\hline & CIM & 0,062 & 0,012 & 0,014 & 0,089 & 0,000 & 0,000 & 0,000 & 0,000 \\
\hline & BI & 54 & 50 & 89 & 94 & 72 & 00 & 00 & 72 \\
\hline \multirow{3}{*}{ Iran } & \multirow{2}{*}{ PB } & 0,046 & 0,106 & 0,035 & 0,188 & 0,001 & 0,000 & 0,000 & 0,001 \\
\hline & & 68 & 16 & 40 & 24 & 11 & 00 & 00 & 11 \\
\hline & SB & 0,016 & 0,098 & 0,016 & 0,132 & 0,000 & 0,000 & 0,000 & 0,000 \\
\hline
\end{tabular}




\begin{tabular}{|c|c|c|c|c|c|c|c|c|c|}
\hline & & 73 & 54 & 81 & 08 & 78 & 00 & 00 & 78 \\
\hline & & 0,009 & 0,064 & 0,036 & 0,110 & 0,000 & 0,000 & 0,000 & 0,000 \\
\hline & IB & 50 & 76 & 28 & 54 & 64 & 00 & 00 & 64 \\
\hline \multirow{6}{*}{$\begin{array}{l}\text { Arab } \\
\text { Saudi }\end{array}$} & \multirow{2}{*}{ ARB } & 0,063 & 0,000 & 0,042 & 0,106 & 0,002 & 0,004 & 0,032 & 0,039 \\
\hline & & 80 & 00 & 23 & 03 & 28 & 60 & 30 & 18 \\
\hline & \multirow{2}{*}{$\mathrm{AB}$} & 0,057 & 0,000 & 0,029 & 0,086 & 0,001 & 0,025 & 0,038 & 0,065 \\
\hline & & 43 & 00 & 42 & 85 & 54 & 82 & 59 & 95 \\
\hline & \multirow{2}{*}{ BA } & 0,043 & 0,000 & 0,046 & 0,089 & 0,001 & 0,002 & 0,042 & 0,046 \\
\hline & & 03 & 00 & 90 & 93 & 27 & 18 & 99 & 44 \\
\hline \multirow{6}{*}{$\begin{array}{l}\text { Uni } \\
\text { Emirat } \\
\text { Arab }\end{array}$} & \multirow{2}{*}{ ADIB } & 0,040 & 0,003 & 0,031 & 0,075 & 0,001 & 0,000 & 0,032 & 0,034 \\
\hline & & 65 & 72 & 52 & 90 & 47 & 18 & 58 & 23 \\
\hline & \multirow{2}{*}{ DIB } & 0,067 & 0,042 & 0,025 & 0,135 & 0,002 & 0,000 & 0,047 & 0,049 \\
\hline & & 60 & 45 & 65 & 69 & 02 & 09 & 87 & 98 \\
\hline & \multirow{2}{*}{ EIB } & 0,079 & 0,008 & 0,025 & 0,114 & 0,000 & 0,002 & 0,000 & 0,002 \\
\hline & & 70 & 58 & 76 & 04 & 77 & 03 & 00 & 79 \\
\hline \multirow{6}{*}{ Kuwait } & \multirow{2}{*}{ KFH } & 0,054 & 0,000 & 0,016 & 0,070 & 0,000 & 0,002 & 0,082 & 0,086 \\
\hline & & 83 & 00 & 13 & 96 & 97 & 86 & 65 & 48 \\
\hline & \multirow{2}{*}{ BB } & 0,068 & 0,000 & 0,015 & 0,084 & 0,000 & 0,000 & 0,000 & 0,001 \\
\hline & & 67 & 00 & 48 & 15 & 89 & 89 & 00 & 78 \\
\hline & \multirow{2}{*}{ AUB } & 0,058 & 0,000 & 0,018 & 0,076 & 0,001 & 0,000 & 0,000 & 0,002 \\
\hline & & 10 & 00 & 08 & 18 & 20 & 91 & 00 & 11 \\
\hline \multirow{6}{*}{ Qatar } & \multirow{2}{*}{ QIB } & 0,086 & 0,005 & 0,019 & 0,111 & 0,001 & 0,000 & 0,028 & 0,030 \\
\hline & & 37 & 51 & 63 & 50 & 61 & 00 & 68 & 29 \\
\hline & \multirow{2}{*}{ MAR } & 0,100 & 0,025 & 0,010 & 0,135 & 0,002 & 0,000 & 0,005 & 0,007 \\
\hline & & 36 & 27 & 26 & 89 & 42 & 00 & 52 & 93 \\
\hline & \multirow{2}{*}{ BwB } & 0,077 & 0,004 & 0,013 & 0,095 & 0,001 & 0,000 & 0,052 & 0,054 \\
\hline & & 99 & 46 & 25 & 70 & 59 & 00 & 47 & 05 \\
\hline
\end{tabular}

Secara keseluruhan Parsian Bank (PB) lebih baik dalam mencapai tujuan kedua (pembentukan keadilan) dibandingkan dengan bank syariah lainnya. Keunggulan PB dalam mencapai tujuan kedua disebabkan oleh tingginya investasi dengan sistem bagi hasil yang disalurkan oleh PB selama periode 2013 - 2015.

Kemudian terlihat bahwa Masraf Al Rayan (MAR) unggul pada indikator kinerja terkait profitabilitas bank. Sementara Alinma Bank (AB) memiliki indikator kinerja zakat tertinggi dibandingkan dengan bank syariah lainnya. Dan secara umum Kuwait Finance House (KFH) memperoleh nilai tertinggi dalam mencapai tujuan ketiga (kepentingan publik). Hal ini dikarenakan tingginya investasi $\mathrm{KFH}$ pada sektor ekonomi riil selama periode $2013-2015$.

\subsection{MAOASID INDEX (MI) BANK SYARIAH}

Tabel 6. Maqasid Index Bank Syariah Periode 2013 - 2015

\begin{tabular}{cccccc}
\hline \multirow{3}{*}{ Negara } & $\begin{array}{c}\text { Nama } \\
\text { Bank }\end{array}$ & IK (T2) & IK (T3) & $\begin{array}{c}\text { MI } \\
{[\text { IK (T2) + IK }} \\
\text { (T3) }\end{array}$ & Peringkat \\
\hline \multirow{3}{*}{ Indonesia } & BSM & 0,13664 & 0,06863 & $\mathbf{0 , 2 0 5 2 7}$ & 1 \\
\cline { 2 - 6 } & BMS & 0,05810 & 0,02217 & 0,08027 & 20 \\
\cline { 2 - 6 } & BNIS & 0,09619 & 0,02318 & 0,11937 & 13 \\
\hline Malaysia & BIMB & 0,08298 & 0,01471 & 0,09769 & 17 \\
\hline
\end{tabular}




\begin{tabular}{lllllc} 
& BMMB & 0,12981 & 0,01674 & 0,14655 & 7 \\
\cline { 2 - 6 } & CIMBI & 0,08994 & 0,00072 & 0,09066 & 18 \\
\hline \multirow{3}{*}{ Iran } & PB & $\mathbf{0 , 1 8 8 2 4}$ & 0,00111 & 0,18935 & 2 \\
\cline { 2 - 6 } & SB & 0,13208 & 0,00078 & 0,13286 & 12 \\
\cline { 2 - 6 } & TB & 0,11054 & 0,00064 & 0,11117 & 15 \\
\hline \multirow{3}{*}{ Arab Saudi } & ARB & 0,10603 & 0,03918 & 0,14521 & 8 \\
\cline { 2 - 6 } & AB & 0,08685 & 0,06595 & 0,15280 & 5 \\
\cline { 2 - 6 } & BA & 0,08993 & 0,04644 & 0,13637 & 11 \\
\hline \multirow{2}{*}{ Uni Emirat } & ADIB & 0,07590 & 0,03423 & 0,11012 & 16 \\
\cline { 2 - 6 } & DIB & 0,13569 & 0,04998 & 0,18567 & 3 \\
\cline { 2 - 6 } & EIB & 0,11404 & 0,00279 & 0,11684 & 14 \\
\hline \multirow{3}{*}{ Kuwait } & KFH & 0,07096 & $\mathbf{0 , 0 8 6 4 8}$ & 0,15744 & 4 \\
\cline { 2 - 6 } & BB & 0,08415 & 0,00178 & 0,08593 & 19 \\
\cline { 2 - 6 } Qatar & AUB & 0,07618 & 0,00211 & 0,07829 & 21 \\
& QIB & 0,11150 & 0,03029 & 0,14179 & 10 \\
\cline { 2 - 6 } & MAR & 0,13589 & 0,00793 & 0,14383 & 9 \\
\cline { 2 - 6 } & BwB & 0,09570 & 0,05405 & 0,14975 & 6
\end{tabular}

Dari tabel 6 di atas terlihat bahwa pencapaian tujuan kedua yaitu pembentukan keadilan dilakukan paling baik oleh Parsian Bank (PB), dan pencapaian tujuan ketiga yaitu kepentingan publik diraih oleh Kuwait Finance House (KFH). Tetapi untuk kinerja secara keseluruhan dilihat dari maqasid index, Bank Syariah Mandiri (BSM) memiliki nilai tertinggi. Hal ini dikarenakan BSM memiliki pencapaian yang cukup bagus di kedua tujuan, tujuan pembentukan keadilan maupun tujuan kepentingan publik.

\subsection{UJI NORMALITAS DATA}

Dalam menguji normalitas data, peneliti menggunakan Kolmogorov-Smirnov Test. Diperoleh semua indikator dalam penelitian ini yaitu keadilan (tujuan kedua), maslahah (tujuan ketiga), dan maqasid index menunjukkan data terdistribusi normal. Diketahui nilai semua indikator adalah $\alpha>0,05$, hal ini berarti hipotesis nol tidak ditolak atau data terdistribusi secara normal.

Tabel 7. One-Sample Kolmogorov-Smirnov Test

\begin{tabular}{|c|c|c|c|c|}
\hline & & Keadilan & Maslahah & $\begin{array}{l}\text { Maqasid } \\
\text { Index }\end{array}$ \\
\hline & & 21 & 21 & 21 \\
\hline \multirow[t]{2}{*}{ Normal Parameters } & Mean &, 105111 &, 027138 &, 132249 \\
\hline & $\begin{array}{l}\text { Std. } \\
\text { Deviation }\end{array}$ & ,0301937 & ,0263435 & ,0356684 \\
\hline \multirow{3}{*}{$\begin{array}{l}\text { Most Extr } \\
\text { Differences }\end{array}$} & Absolute & , 140 & , 157 & ,097 \\
\hline & Positive & , 140 & , 156 & ,097 \\
\hline & Negative &,- 081 &,- 157 &,- 082 \\
\hline Test Statistic & &, 140 &, 157 & , 097 \\
\hline
\end{tabular}




\begin{abstract}
\begin{tabular}{llll}
\hline Asymp. Sig. (2-tailed) &, $200^{\mathrm{c}, \mathrm{d}}$ &, $190^{\mathrm{c}}$ &, $200^{\mathrm{c}, \mathrm{d}}$ \\
\hline
\end{tabular}
Dari tabel diatas terlihat nilai test statistic untuk keadilan 0,140 dengan probabilitas signifikansi 0,200 dan nilai $\alpha>0,05$, hal ini berarti hipotesis nol tidak ditolak atau keadilan terdistribusi secara normal. Sedangkan nilai test statistic untuk maslahah 0,157 dengan probabilitas signifikansi 0,190 dan nilai $\alpha>0,05$, hal ini berarti hipotesis nol tidak ditolak atau maslahah terdistribusi secara normal. Begitu juga dengan nilai test statistic untuk maqasid index 0,097 dengan probabilitas signifikansi 0,200 dan nilai $\alpha>0,05$, hal ini berarti hipotesis nol tidak ditolak atau maqasid index terdistribusi secara normal.
\end{abstract}

\title{
4.5 UJI ANALISIS DESKRIPTIF
}

Jika dilihat dari rata-rata per negara, rata-rata perbankan syariah Indonesia $(0,09698)$ lebih baik dibandingkan dengan perbankan syariah Arab Saudi $(0,09427)$ dan Kuwait $(0,07710)$ dalam mencapai tujuan kedua yaitu pembentukan keadilan, tetapi tidak lebih baik dari Iran yang memiliki ratarata tertinggi $(0,14362)$. Dalam mencapai tujuan ketiga yaitu kepentingan publik, rata-rata perbankan syariah Indonesia (0,03799) lebih baik dibandingkan dengan perbankan syariah Malaysia (0,01073), Iran $(0,00084)$, Uni Emirat Arab (0,02900), Kuwait (0,03012), dan Qatar (0,03076), tetapi tidak lebih baik dari perbankan syariah Arab Saudi yang memiliki rata-rata tertinggi $(0,05052)$ dalam mencapai tujuan kepentingan publik. Sedangkan untuk kinerja secara keseluruhan yang dilihat dari maqasid index (MI), ratarata perbankan syariah Indonesia $(0,13497)$ lebih baik dibandingkan dengan perbankan syariah Malaysia $(0,11163)$ dan Kuwait $(0,10722)$, tetapi tidak lebih baik dari Qatar yang memiliki rata-rata tertinggi $(0,14512)$ untuk maqasid index.

Tabel 8. Rata-Rata Kinerja Perbankan Syariah di Setiap Negara

\begin{tabular}{|c|c|c|c|c|}
\hline Negara & Nama Bank & IK (T2) & IK (T3) & $\begin{array}{c}\mathrm{MI} \\
{[\mathrm{IK}(\mathrm{T} 2)+\mathrm{IK}} \\
(\mathrm{T} 3)]\end{array}$ \\
\hline \multirow{4}{*}{ Indonesia } & $\begin{array}{l}\text { Bank Syariah } \\
\text { Mandiri }\end{array}$ & 0,13664 & 0,06863 & 0,20527 \\
\hline & $\begin{array}{l}\text { Bank Mega } \\
\text { Syariah }\end{array}$ & 0,05810 & 0,02217 & 0,08027 \\
\hline & BNI Syariah & 0,09619 & 0,02318 & 0,11937 \\
\hline & Rata-Rata & 0,09698 & 0,03799 & 0,13497 \\
\hline \multirow{3}{*}{ Malaysia } & $\begin{array}{l}\text { Bank Islam } \\
\text { Malaysia } \\
\text { Berhad }\end{array}$ & 0,08298 & 0,01471 & 0,09769 \\
\hline & $\begin{array}{l}\text { Bank } \\
\text { Muamalat } \\
\text { Malaysia } \\
\text { Berhad }\end{array}$ & 0,12981 & 0.01674 & 0,14655 \\
\hline & CIMB Islamic & 0,08994 & 0,00072 & 0,09066 \\
\hline
\end{tabular}




\begin{tabular}{|c|c|c|c|c|}
\hline Negara & Nama Bank & IK (T2) & IK (T3) & $\begin{array}{c}\mathrm{MI} \\
{[\mathrm{IK}(\mathrm{T} 2)+\mathrm{IK}} \\
(\mathrm{T} 3)]\end{array}$ \\
\hline & Bank Berhad & & & \\
\hline & Rata-Rata & 0,10091 & 0,01073 & 0,11163 \\
\hline \multirow{4}{*}{ Iran } & Parsian Bank & 0,18824 & 0,00111 & 0,18935 \\
\hline & Saman Bank & 0,13208 & 0,00078 & 0,13286 \\
\hline & Tejarat Bank & 0,11054 & 0,00064 & 0,11117 \\
\hline & Rata-Rata & 0,14362 & 0,00084 & 0,14446 \\
\hline \multirow{4}{*}{ Arab Saudi } & Al Rajhi Bank & 0,10603 & 0,03918 & 0,14521 \\
\hline & Alinma Bank & 0,08685 & 0,06595 & 0,15280 \\
\hline & Bank AlJazira & 0,08993 & 0,04644 & 0,13637 \\
\hline & Rata-Rata & 0,09427 & 0,05052 & 0,14479 \\
\hline \multirow{4}{*}{$\begin{array}{l}\text { Uni Emirat } \\
\text { Arab }\end{array}$} & $\begin{array}{l}\text { Abu Dhabi } \\
\text { Islamic Bank }\end{array}$ & 0,07590 & 0,03423 & 0,11012 \\
\hline & $\begin{array}{l}\text { Dubai Islamic } \\
\text { Bank }\end{array}$ & 0,13569 & 0,04998 & 0,18567 \\
\hline & $\begin{array}{l}\text { Emirates } \\
\text { Islamic Bank }\end{array}$ & 0,11404 & 0,00279 & 0,11684 \\
\hline & Rata-Rata & 0,10854 & 0,02900 & 0,13754 \\
\hline \multirow{4}{*}{ Kuwait } & $\begin{array}{l}\text { Kuwait } \\
\text { Finance } \\
\text { House } \\
\end{array}$ & 0,07096 & 0,08648 & 0,15744 \\
\hline & $\begin{array}{l}\text { Boubyan } \\
\text { Bank } \\
\end{array}$ & 0,08415 & 0,00178 & 0,08593 \\
\hline & $\begin{array}{ll}\text { Ahli } & \text { United } \\
\text { Bank } & \\
\end{array}$ & 0,07618 & 0,00211 & 0,07829 \\
\hline & Rata-Rata & 0,07710 & 0,03012 & 0,10722 \\
\hline \multirow{4}{*}{ Qatar } & $\begin{array}{ll}\text { Qatar } & \text { Islamic } \\
\text { Bank } & \\
\end{array}$ & 0,11150 & 0,03029 & 0,14179 \\
\hline & $\begin{array}{ll}\text { Masraf } & \mathrm{Al} \\
\text { Rayan } & \\
\end{array}$ & 0,13589 & 0,00793 & 0,14383 \\
\hline & Barwa Bank & 0,09570 & 0,05405 & 0,14975 \\
\hline & Rata-Rata & 0,11437 & 0,03076 & 0,14512 \\
\hline
\end{tabular}

Keterangan: IK (T2) = Tujuan Pembentukan Keadilan, IK (T3) = Tujuan Kepentingan Publik, dan $\mathrm{MI}=$ Maqasid Index .

\subsection{UJI HIPOTESIS}

Untuk dapat menggunakan uji statistik ANOVA harus dipenuhi asumsi homogeneity of variance. Levene's test of homogeneity of variance seperti tabel 4.9 di bawah ini dihitung oleh SPSS untuk menguji asumsi ANOVA bahwa bank syariah di tujuh negara memiliki varians sama. 
Tabel 9. Test of Homogeneity of Variance

\begin{tabular}{lrrrrr}
\hline & Levene Statistic & df1 & df2 & Sig. \\
\hline Keadilan & 1,524 & 6 & 14 &, 241 \\
\hline Maslahah & 4,434 & 6 & 14 &, 010 \\
\hline Maqasid Index & 3,155 & 6 & 14 &, 036 \\
\hline
\end{tabular}

Hasil uji test of homogeneity of variance menunjukkan bahwa nilai levene statistic untuk keadilan (tujuan kedua) sebesar 1,524 dan tidak signifikan pada 0,05 (probabilitas > 0,05) yang berarti tidak dapat menolak hipotesis nol yang menyatakan varians sama. Sedangkan untuk maslahah (tujuan ketiga) dan maqasid index nilai levene statistic adalah sebesar 4,434 dan 3,155 dan keduanya signifikan pada 0,05 (probabilitas $<0,05$ ) yang berarti dapat menolak hipotesis nol yang menyatakan bahwa varians tidak sama (berbeda), hal ini menurut Ghozali (2013) tidak fatal untuk ANOVA dan analisis masih dapat diteruskan sepanjang grup memiliki ukuran sampel yang sama (secara proporsional). Selanjutnya untuk melihat apakah ada perbedaan kinerja dari ketujuh negara dapat dilihat di tabel ANOVA di bawah ini:

Tabel 10. ANOVA

\begin{tabular}{|c|c|c|c|c|c|c|}
\hline & & $\begin{array}{c}\text { Sum of } \\
\text { Squares }\end{array}$ & df & $\begin{array}{c}\text { Mean } \\
\text { Square }\end{array}$ & $\mathrm{F}$ & Sig. \\
\hline \multirow[t]{3}{*}{ Keadilan } & Between Groups & ,008 & 6 & ,001 & 1,706 &, 192 \\
\hline & Within Groups & 011 & 14 & ,001 & & \\
\hline & Total & 018 & 20 & & & \\
\hline \multirow[t]{3}{*}{ Maslahah } & Between Groups &, 005 & 6 & ,001 & 1,295 & ,321 \\
\hline & Within Groups &, 009 & 14 & ,001 & & \\
\hline & Total &, 014 & 20 & & & \\
\hline \multirow{3}{*}{$\begin{array}{l}\text { Maqasid } \\
\text { Index }\end{array}$} & Between Groups &, 005 & 6 & ,001 &, 526 & ,780 \\
\hline & Within Groups &, 021 & 14 & ,001 & & \\
\hline & Total &, 025 & 20 & & & \\
\hline
\end{tabular}

Nilai $\mathrm{F}$ hitung keadilan (tujuan kedua) sebesar 1,706 dengan probabilitas 0,192 pada kolom Sig. yang berarti $\mathrm{p}>0,05$ maka ketujuh negara mempunyai rata-rata keadilan yang tidak berbeda (signifikan), dengan demikian pada taraf nyata $=0,05$ menolak hipotesis dua $\left(\mathrm{H}_{2}\right)$ sehingga kesimpulan yang didapatkan adalah tidak adanya perbedaan yang signifikan dari tujuan syariah kedua (pembentukan keadilan) antara perbankan syariah Indonesia dengan perbankan syariah di Malaysia, Iran, Arab Saudi, Uni Emirat Arab, Kuwait, dan Qatar.

Sedangkan untuk F hitung maslahah (tujuan ketiga) sebesar 1,295 dengan probabilitas 0,321 yang berarti $\mathrm{p}>0,05$ maka ketujuh negara mempunyai rata-rata maslahah yang tidak berbeda (signifikan), dengan demikian pada taraf nyata $=0,05$ menolak hipotesis tiga $\left(\mathrm{H}_{3}\right)$ sehingga kesimpulan yang didapatkan adalah tidak adanya perbedaan yang signifikan dari tujuan syariah ketiga (kepentingan publik) antara perbankan syariah Indonesia dengan perbankan syariah di Malaysia, Iran, Arab Saudi, Uni Emirat Arab, Kuwait, dan Qatar. 
Begitu pula dengan maqasid index yang memiliki nilai $\mathrm{F}$ hitung sebesar 0,526 dengan probabilitas 0,780 pada kolom Sig. yang berarti $\mathrm{p}>$ 0,05 maka ketujuh negara mempunyai rata-rata maqasid index yang tidak berbeda (signifikan), dengan demikian pada taraf nyata $=0,05$ menolak hipotesis satu $\left(\mathrm{H}_{1}\right)$ sehingga kesimpulan yang didapatkan adalah tidak terdapat perbedaan yang signifikan dari maqasid index antara perbankan syariah Indonesia dengan perbankan syariah di Malaysia, Iran, Arab Saudi, Uni Emirat Arab, Kuwait, dan Qatar.

Karena hasil uji ANOVA menunjukkan tidak adanya perbedaan yang signifikan dari maqasid index, tujuan pembentukan keadilan, dan tujuan kepentingan publik yang diteliti antara ketujuh negara, maka uji lanjut post hoc test tidak perlu dilakukan, karena post hoc test digunakan untuk melihat berapa besarnya perbedaan masing-masing indikator di tujuh negara. Namun apabila hasil uji ANOVA menunjukkan adanya perbedaan yang signifikan, maka uji lanjut post hoc test harus dilakukan.

Dari hasil uji deskriptif dan uji hipotesis dalam penelitian ini menunjukkan bahwa perbankan syariah Indonesia harus lebih mengupayakan usahanya dalam memastikan kejujuran dan keadilan dalam semua transaksi, maupun kegiatan usaha yang dapat menciptakan ketidakadilan seperti riba, kecurangan, dan korupsi. Hal ini semata-mata untuk pencapaian tujuan syariah pembentukan keadilan yang lebih baik lagi karena perbankan syariah Indonesia masih kalah dengan perbankan syariah di Malaysia, Iran, Uni Emirat Arab, dan Qatar. Tujuan kepentingan publik pada perbankan syariah Indonesia sudah bagus dalam memberikan manfaat yang lebih bagi masyarakat terhadap aktivitas bisnis yang dijalankannya, maka perbankan syariah Indonesia perlu untuk mempertahankan dan meningkatkannya karena masih kurang baik bila dibandingkan dengan perbankan syariah Arab Saudi. Perlu adanya peningkatan kinerja secara keseluruhan pada perbankan syariah Indonesia karena masih kurang baik bila dibandingkan dengan perbankan syariah di Iran, Arab Saudi, Uni Emirat Arab, dan Qatar.

Hasil penelitian ini sejalan dengan Ramadhani dan Mutia (2016) yang menemukan tidak terdapat perbedaan pencapaian kinerja dengan pendekatan maqasid syariah antara bank Malaysia dan bank Indonesia. Mohammed dan Razak (2008) juga menyatakan tidak terdapat perbedaan bank syariah di Malaysia, Indonesia, Yordania, Bahrain, Sudan dan Bangladesh dalam mengungkapkan kinerja dengan pendekatan maqasid syariah. Tidak satu pun bank memperoleh nilai tinggi dalam ke semua pengukuran kinerja. Adanya sejumlah variasi dalam laporan tahunan menunjukkan inkonsistensi dalam mencapai maqasid syariah.

Pengukuran kinerja dengan pendekatan maqasid syariah perlu diterapkan oleh industi perbankan syariah, dibanding hanya fokus pada rasio keuangan. Untuk itu bank seharusnya mendukung ketersediaan data dengan menyiapkan sejumlah laporan, diantaranya: laporan aktivitas pemegang saham, laporan aktivitas pegawai, aktivitas terkait nasabah (pendanaan, pembiayaan dan jasa), dan CSR (Antonio, et.al, 2012). Zakariyah (2015) juga 
mengharapkan agar adanya aturan untuk menggabungkan aspek moral, sehingga industri bisa mewujudkan pencapaian maqasid syariah ini.

\section{SIMPULAN}

Kesimpulan dalam penelitian ini adalah hasil uji hipotesis ANOVA untuk maqasid index, tujuan syariah pembentukan keadilan, dan tujuan syariah kepentingan publik menunjukkan tidak terdapat perbedaan yang signifikan antara perbankan syariah di Indonesia dengan perbankan syariah di Malaysia, Iran, Arab Saudi, Uni Emirat Arab, Kuwait, dan Qatar.

Perlu dilakukannya penelitian lanjutan dengan memperpanjang data sampel lebih dari 3 tahun dan memperbanyak sampel bank syariah. Dan tidak hanya pada kawasan Asia saja tetapi bisa lebih luas lagi cakupan negara sampelnya misal di tingkat global. Penelitian ini diharapkan akan menginspirasi para peneliti lain di bidang akuntansi untuk membuktikan bahwa informasi akuntansi dalam bentuk rasio memiliki konten atau isi ketika digunakan untuk mendeteksi kinerja perbankan syariah.

\section{DAFTAR PUSATAKA}

Abu Zahara, Muhammad. (1997). Usul al-Fiqh. Cairo: Dar al-Fikr al-'Arabi.

Al Arif, M. N. R \& Yuke R. (2015). Manajemen Risiko Perbankan Syariah. Jakarta: UIN PRESS.

Alamsyah, Halim. (2012). Perkembangan dan Prospek Perbankan Syariah Indonesia: Tantangan Dalam Menyongsong MEA 2015. Milad ke-8 Ikatan Ahli Ekonomi Islam (IAEI).

Alamsyah, Ichsan Emrald. Syariah Dominasi Perbankan Kuwait. http://www.republika.co.id/berita/koran/syariahkoran/14/08/04/n9rwyl21-syariah-dominasi-perbankan-kuwait. Diakses pada 4 Agustus 2014.

Alhozaimy, Yousef. (2009). The Islamisation of Saudi Arabian Monetary Agency (SAMA) and the Financial System in the Kingdom of Saudi Arabia, Experience from Selected Muslim Countries. Bangor Business School, Bangor University, United Kingdom.

Almazari, A. A. (2014). Impact of internal factors on bank profitability: Comparative study between Saudi Arabia and Jordan. Journal of Applied Finance and banking, 4(1), 125.

Amin, A. Riawan. (2009). Menata Perbankan Syariah di Indonesia. Jakarta: UIN Press. 
Ascarya. (2006). Akad dan Produk Bank Syariah: Konsep dan Praktek di Beberapa Negara. Jakarta: Bank Indonesia.

Asma'Rashidah Idris, F. F. A., Asari, H., Taufik, N. A. A., Salim, N. J., Mustaffa, R., \& Jusoff, K. (2011). Determinant of Islamic banking institutions' profitability in Malaysia. World Appl. Sci. J, 12, 01-07.

Bank Indonesia. (2007). Cetak Biru Pengembangan Perbankan Syariah di Indonesia. $\quad$ http://www.bi.go.id/id/ruang-media/siaranpers/Documents/cetakbirups.pdf. Diakses pada 26 Juli 2016.

Ben Selma Mokni, R., \& Rachdi, H. (2014). Assessing the bank profitability in the MENA region: A comparative analysis between conventional and Islamic bank. International Journal of Islamic and Middle Eastern Finance and Management, 7(3), 305-332.

Bley, J., \& Kuehn, K. (2004). Conventional versus Islamic finance: student knowledge and perception in the United Arab Emirates. International Journal of Islamic Financial Services, 5(4), 17-30.

Dream. 15 Bank Syariah Paling Pandai Cari Uang di Dunia. http://www.dream.co.id/dinar/15-bank-syariah-paling-pandai-cariuang-di-dunia-151023z.html. Diakses pada 23 Oktober 2015.

Ghozali, Imam. (2013). Aplikasi Analisis Multivariate dengan Program IBM SPSS 21. Semarang: Badan Penerbit Universitas Diponegoro.

Global Islamic Financial Report (GIFR) 2013

Global Islamic Financial Report (GIFR). (2016). Islamic Finance Country Index - IFCI 2016. Islamic Financial Policy.

Hasan, Zubairi. (2009). Undang-undang Perbankan Syariah: Titik Temu Hukum Islam dan Hukum Nasional. Jakarta: PT RajaGrafindo Persada.

Horngren, Charles T. \& Gary L. Sundem. (1993). Introduction to Management Accounting. New Jersey: Prentice Hall.

Hukmi, Puri. Saudi Arabia Berpotensi Menyalip Malaysia Sebagai Penerbit Sukuk Global Terbesar dalam Waktu Dekat. http://www.ekonomisyariah.org/?page=newsview\&command=detail\& sheet=1\&id1=587. Diakses pada 26 September 2012.

Ibrahim, M. (2015). Measuring the financial performance of Islamic Banks. Journal of Applied finance and Banking, 5(3), 93.

Ihsan, Dwi Nur'aini. (2013). Analisis Laporan Keuangan Perbankan Syariah. Jakarta: UIN Jakarta Press.

Imansari, Anisa Dyah. (2015). Analisis Perbandingan Kinerja Perbankan Syariah Berdasarkan Konsep Al-Maqashid Al-Syariah di Indonesia dan Malaysia. Fakultas Ekonomi dan Bisnis Universitas Diponegoro. 
Kasmir. (2002). Dasar-dasar Perbankan. Jakarta: PT. Raja Grafindo Persada.

Kasmir. (2014). Manajemen Perbankan. Jakarta: PT. RajaGrafindo Persada.

Lavinda. Indonesia Duduki Peringkat 9 Negara Beraset Syariah Terbesar Dunia. http://syariah.bisnis.com/read/20140904/86/255136/indonesiaduduki-peringkat-9-negara-beraset-syariah-terbesar-dunia. Diakses pada 4 September 2014.

Lee, Mei Pheng dan Ivan Jeron Detta. (2007). Islamic Banking \& Finance Law. Kuala Lumpur: Pearson Malaysia.

Mohammed, M. O., \& Taib, F. M. (2015). Developing Islamic banking performance measures based on Maqasid al-Shari'ah framework: Cases of 24 selected banks. Journal of Islamic Monetary Economics and Finance, 1(1), 55-77.

Mohammed, Mustafa Omar. (2008). The Performance Measures of Islamic Banking Based on the Maqasid Framework. IIUM International Accounting Conference (INTAC IV).

Mulyadi. (2000). Akuntansi Manajemen: Konsep, Manfaat dan Rekayasa. Yogyakarta: Bagian Penerbitan Sekolah Tinggi Ilmu Ekonomi YKPN.

Nazir, Moh. (2009). Metode Penelitian. Jakarta: Ghalia Indonesia.

Otoritas Jasa Keuangan. (2014). Peraturan Otoritas Jasa Keuangan No. 8/POJK.03/2014 tentang Penilaian Tingkat Kesehatan Bank Umum Syariah dan Unit Usaha Syariah. http://www.ojk.go.id/id/kanal/syariah/regulasi/peraturan-ojk-terkaitsyariah/Pages/39peraturan-otoritas-jasa-keuangan-tentang-penilaiantingkat-kesehatan-bank-umum-syariah-dan-unit-usaha-syariah.aspx. Diakses pada 6 April 2016.

Otoritas Jasa Keuangan. (2016). Statistik Perbankan Indonesia - Vol. 14, No. 6, Mei 2016. http://www.ojk.go.id/id/kanal/perbankan/data-danstatistik/statistik-perbankan-indonesia/Pages/Statistik-PerbankanIndonesia---Mei-2016.aspx. Diakses pada 5 Agustus 2016.

Ramadhani, Riky dan Evi Mutia. (2016). Analisis Perbandingan Kinerja Perbankan Syariah di Indonesia dan Malaysia ditinjau dari Pendekatan Maqasid Syariah Indeks. Simposium Nasional Akuntansi XIX. Diselenggarakan di Lampung pada tanggal 24-27 Agustus 2016.

Reza, Ali. (2010). Perbandingan Kondisi Perbankan Syariah di Republik Islam Iran dan Indonesia. Fakultas Syariah dan Hukum UIN Jakarta.

Rostanti, Qommarria. Aset Perbankan Syariah Qatar Diprediksi Capai 100 Miliar Dolar AS. http://www.republika.co.id/berita/ekonomi/syariahekonomi/13/09/20/mten2r-aset-perbankan-syariah-qatar-diprediksicapai-100-miliar-dolar-as. Diakses pada 20 September 2013. 
Rostanti, Qommarria. Dua Bank Syariah Qatar Jalin Kerja Sama Murabahah. http://www.republika.co.id/berita/ekonomi/syariahekonomi/13/06/12/mo9pc9-dua-bank-syariah-qatar-jalin-kerja-samamurabahah. Diakses pada 12 Juni 2013.

Samad, A., \& Hassan, M. K. (1999). The performance of Malaysian Islamic bank during 1984-1997: An exploratory study. International Journal of Islamic Financial Services, 1(3), 1-14.

Sanrego, Y. D., Antonio, M. S., \& Taufiq, M. (2012). An Analysis of Islamic Banking Performance: Maqashid Index Implementation in Indonesia and Jordania. Journal of Islamic Finance, 1(1), 12-29.

Santoso, Totok Budi dan Sigit Triandaru. (2006). Bank dan Lembaga Keuangan Lain. Jakarta: Salemba Empat.

Siamat, Dahlan. (2005). Manajemen Lembaga Keuangan Edisi Kelima. Jakarta: Fakultas Ekonomi Universitas Indonesia.

Siraj, K. K., \& Pillai, P. S. (2012). Comparative study on performance of Islamic banks and conventional banks in GCC region. Journal of Applied Finance and Banking, 2(3), 123.

Sjahdeini, Sutan Remy. (2010). Perbankan Syariah. Jakarta: Jayakarta Agung Offset.

Sudiyatno, Bambang, Jati Suroso. (2010). Analisis Pengaruh Dana Pihak Ketiga, BOPO, CAR, dan LDR terhadap Kinerja Keuangan pada Sektor Perbankan yang Go Public di Bursa Efek Indonesia (BEI) (Periode 2005-2008). Dinamika Keuangan dan Perbankan: Semarang.

Sugiyono. (2011). Statistika untuk Penelitian. Bandung: Alfabeta.

Suharso, Yudi. Industri Bank Syariah di Qatar Terus Bertumbuh Lebih Cepat. http://mysharing.co/industri-bank-syariah-di-qatar-terusbertumbuh-lebih-cepat/. Diakses pada 20 Oktober 2014.

Syukron, A. (2013). Dinamika Perkembangan Perbankan Syariah Di Indonesia. Economic: Journal of Economic and Islamic Law, 3(2), 2853.

Undang-Undang Nomor 10 Tahun 1998

Undang-Undang Nomor 21 Tahun 2008

Veithzal, Rivai. (2007). Bank and Financial Institution Management. Jakarta: PT. Raja Grafindo Persada.

Weston, J. Fred \& Eugene F. Brigham. (1993). Manajemen Keuangan. Jakarta: Salemba Empat.

Wibowo, S. (2015). Analisis Perbandingan Kinerja Keuangan Perbankan Syariah dengan Metode CAMEL di ASEAN (Studi Komparatif: 
Indonesia, Malaysia, Thailand). Jurnal Riset Ekonomi dan Manajemen, 15(1), 136-153.

Widjanarto. (2003). Hukum dan Ketentuan Perbankan di Indonesia Edisi IV. Jakarta: PT Pustaka Utama Grafiti.

Zanganeh, M. (2015). Supervising Islamic Financial Institutions: Islamic Banking in The Countries Compared. Economic: Journal of Economic and Islamic Law, 5(1), 50-70.

https://www.syariahmandiri.co.id/category/investor-relation/laporan-tahunan/ http://www.megasyariah.co.id/\#article5

http://www.bnisyariah.co.id/category/investor-relations/laporan-tahunan http://www.bankislam.com.my/home/corporate-info/annual-reports/ http://www.muamalat.com.my/corporate-overview/financials/2015.html http://www.cimbislamic.com/en/investor-relations.html http://www.parsianbank.ir/portal/Home/Default.aspx?CategoryID=c83b4f52-4518-479eafe1-468da5b9a878

http://www.sb24.com/En/footer/about-us/annual-reports.html http://www.tejaratbank.ir/financial/1602716-Annual-Report-2014-2015.html http://www.alrajhibank.com.sa/en/investor-relations/pages/financialresults.aspx

http://www.alinma.com.sa/wps/portal/alinma/Alinma/MenuPages/FinancialR eports/AnnualReports

http://www.baj.com.sa/about-us.aspx?page=financial-report\&id=142 http://www.adib.ae/en/Pages/Personal_Investors_Relations_Financial_Result .aspx

http://www.dib.ae/investor-relations/financial-information/financial-reports https://emiratesislamic.ae/eng/about-us/annual-reports/ http://www.kfh.com/en/about/annual-report/index.aspx http://www.ahliunited.com.kw/en/about/investors/index.html http://www.bankboubyan.com/en/about/reports/?cID=235 http://www.qib.com.qa/en/investor-relations/financial-reports.aspx http://www.alrayan.com/en/Annual-Reports http://www.barwabank.com/investor-relations/financial-information/ 